DOI: https://doi.org/10.15407/techned2018.06 $: \underline{026}$

\title{
METHOD OF DETERMINATION OF THREE-PHASE VOLTAGE ASYMMETRY OF FUNDAMENTAL FREQUENCY AND ULTRAHARMONICS
}

Journal

Publisher

ISSN

Issue

Pages
Tekhnichna elektrodynamika

Institute of Electrodynamics National Academy of Science of Ukraine 1607-7970 (print), 2218-1903 (online)

No 6, 2018 (November/December)

$26-29$

\section{Author}

\section{D.K. Makov *}

National Technical University of Ukraine «Igor Sikorsky Kyiv Polytechnic Institute», pr. Peremohy, 37, Kyiv, 03056, Ukraine, e-mail: makodk47@gmail.com

* ORCID ID : http://orcid.org/0000-0003-2760-5504

\section{Abstract}

The new method of digital determination of symmetric phase-sequence system of three-phase electric voltages is presented. It uses the next operations: tuning multiple three frequency of measuring of instantaneous values to fundamental frequency of network voltage; analog-digital transformation of instantaneous values of three networks voltages and memorized it; selection of codes that contain the sought after symmetric phase-sequence; selection of codes of voltage of fundamental frequency. A method differs in simplicity and exactness. References 10 , figures 3. 
Key words: indexes of quality of electric power; negative phase-sequence system of voltages, positive phase-sequence system of voltages, coefficient of asymmetry.

Received: 06.03 .2018

Accepted: 20.03 .2018

Published: 23.10 .2018

\section{References}

1. Standart of Ukraine 13109-97. Norms of quality of electric energy are in the systems of power supply of general-purpose. Kyiv. 1997. (Rus)

2. Mykhalskyi V.M. Means for improving the quality of electrical energy on input and output of frequency converters and voltage ones with pulse-length modulation. Kyiv: Instytut elektrodynamiky NAN Ukrainy, 2013. 340 p. (Ukr)

3. Xing Li, Mei Su, Yao Sun, Handbing Dan, Wenjing Xiong. Modulation strategies based on mathematical construction method for matrix converter extending the input reactive power range. IEEE Transactions on Power Electronics. 2014. Vol. 29. No 2. Pp. 654-664.

4. Shcherba A.A., Podoltsev O.D., Kucheriava I.M., Ushakov V.I. Computer Modeling of Electrothermal Processes and Thermomechanical Stress at Induction Heating of Moving Copper Ingots. Tekhnichna Elektrodynamika. 2013. No 2. Pp. 10-18. (Rus)

5. Shcherba A.A., Kosenkov V.M., Bychkov V.M. Mathematical closed model of electric and magnetic fields in the discharge chamber of an electrohydraulic installation. Surface Engineering and Applied Electrochemistry

. 2015. Vol. 51. Issue 6. Pp. 581-588.

6. Shcherba A.A., Suprunovska N.I., Ivaschenko D.S., Beletsky O.A. Prosesses of energy exchange between nonlinear and linear links of electric equivalent circuit of supercapacitors. $T e$ khnichna Elektrodynamika

. 2015. No 5. Pp. 3-11. (Rus) 
7. Shcherba A.A., Suprunovska N.I., Ivaschenko D.S. Modeling of Nonlinerial Resistence of Electro-Spark Load Taking into Account its Changes During Discharge Current Flowing in the Load and et Zero Current in it. Tekhnichna Elektrodynamika. 2014. No 5. Pp. 23-25. (Rus)

8. Mints M.Ya., Chinkov V.N., Grib O.G. Digital measuring device of asymmetry of three-phase network. Patent of USSR No 746336. Publ. 1980. No 25. (Rus)

9. Tesik Yu. Application of differential method to measuring of indexes of quality of electric power. Pratsi Instytutu Elektrodynamiky Natsionalnoi Akademii Nauk Ukrainy. 2005. № 3(12). Pp. 16-21. (Rus)

10. Shcherba A.A., Serpilin K.L., Makov D.K. Method of the digital measuring of symmetric sequences of voltage of three-phase network. Patent of Ukraine UA № 72534. Publ. 2012. No 16. (Ukr) 